Crustacea there is a primary direct action of light on the chromatophores as well as a secondary action through the eyes, and this primary action undoubtedly plays a part in the colour-change of Leander.

A further difference shown by animals in conditions $(a)$ and $(b)$ respectively lies in the behaviour of the deep-seated chromatophores. In light these are expanded, so that the course of nerve-cord and dorsal blood-vessel, round which many are located, can be plainly seen, and the animal appears translucent. In darkness these chromatophores are contracted, and the animal appears opaque.

Again, there is a very marked difference in the position of eye pigments in animals in conditions $(a)$ and $(b)$. In darkness the eye looks black and has an enormous pupil : in light on a white background it shows a black core and pale margin, while in light on a dark background it looks black all over and shows no pupil.

Thus darkness, and light combined with white background, produce different results on the eyes and on certain of the chromatophores of Leander. Light, however, is not the only factor that can affect the chromatophores, for a considerable expansion of red and yellow types may result from excitement or muscular activity.

\section{E. M. Stephenson.}

\section{University College,}

Exeter.

May 19

${ }^{1}$ Keeble and Gamble, Phil. Trans. Roy. Soc., B, 196, 295; 1904.

${ }^{2}$ Perkins, J. Exp. Zool., 50, 71; 1928

${ }^{3}$ Koller, $Z$. vergl. Physiol. 12,$633 ; 1930$.

- Stephenson, NatuRE, 130, 931, Dec. 17, 1932.

\section{Occurrence of an Enteropneust in Wales}

A small Enteropneust was found by us while shore-collecting on the Anglesey coast of the Menai Straits at the beginning of April 1934. Since then we have obtained a number of specimens from this locality. The animals live in clean sand near the low water mark of spring tides at depths down to nine inches. They were found in association with Arenicola marina, Ensis ensis, Echinocardium cordatum and Ammodytes.

Its identification as a species of Dolichoglossus is justified by the absence of an appendix to the stomochord, of synapticulæ between the gill bars, of genital wings and liver diverticulæ, and the presence of a well-developed ventral non-branchial part of the pharynx, of relatively large ova in the ovaries of female specimens, of an elongated proboscis and of a single proboscis pore on the left side.

The records of occurrence of adult Enteropneusts around the coasts of the British Islands are few, although there is a number of records of the occurrence of Tornaria larvæ. A fragment of a large Balanoglossus sp. was obtained in $\mathbf{1 9 0 0}$ on the Galway coast and Tattersall obtained several specimens of a species of Dolichoglossus, which he named D. ruber, near extreme low tide mark off Coastguard Point, Ballynakill Harbour, Co. Galway'. Assheton' ${ }^{2}$ obtained specimens of Dolichoglossus in the littoral zone at Aros in the Sound of Mull, off the west coast of Scotland in 1907, which proved to be a new species, $D$. serpentinus. Since then $\mathrm{Meek}^{3}$ has recorded a single specimen of Glossobalanus, dredged near the Farne Islands, off the coast of Northumberland, which he named $G$. marginatus. So far as we are aware this is the first record of the occurrence of adult Enteropneusts on the coast of Wales and the fifth for the British Isles.

Although our specimens appear to differ in coloration from $D$. ruber, Tattersall, and in external proportions from $D$. serpentinus, Assheton, some time must elapse before we can determine whether it belongs to either of these species. So far, the internal anatomy of neither $D$. ruber nor $D$. serpentinus has been described in detail.

\section{F. W. Rogers Brambell.}

H. A. CoLE.

Department of Zoology,

University College of North Wales,

Bangor, Caernarvonshire.

${ }^{1}$ W. M. Tattersall, "Ann. Rep. Fish., Ireland", 1902-3, Pt. II, App. VII, 1905.

${ }^{2}$ R. Assheton, Zool. Anz., 33 ; 1908.

${ }^{3}$ A. Meek, Q. J. Micro. Soc., 68 ; 1922.

\section{The Theory of Two Factors versus the Sampling Theory of Mental Ability}

Dr. William Brown has published in Nature of May 12 a communication on "The Theory of Two Factors versus the Sampling Theory of Mental Ability". The matter is too involved to be discussed adequately in a letter, but $I$ wish to record that $I$ do not agree that this otherwise very valuable experiment is an experimentum crucis between my views and those of Prof. Spearman, partly because I do not think Dr. Mackie's formulæ are applicable in this way, but mainly because the tetrad-differences had been trimmed down to the narrow scatter shown, by the choice of tests, by the rejection of one of those originally chosen, by the rejection of one of the remaining correlation coefficients, and by the elimination by partial correlation of a large group factor. It is not in dispute that by these means a set of tests can be arrived at which give zero tetrads within the limits of sampling error and can then be described by a parameter $g$ and as many parameters $s$ as there are tests. I would like to add that I admire and value the work done by Dr. Brown and Dr. Stephenson in arriving at the present series of tests.

The University, Edinburgh.

\section{GODFREy H. Thomson.} May 19.

\section{Distribution of Separates of Certain Papers by the late Dr. Bashford Dean}

There have been placed in my hands, by Mrs. Bashford Dean, for distribution among students of fishes, certain reprints of Dr. Dean's studies on the archaic fishes, found among his effects after his untimely death.

If research men who are interested in the morpho. logy, anatomy and embryology of the cyclostomes, sharks and ganoids will go through Dr. Dean's bibliography either in vol. 1 of the "Bibliography of Fishes" or in Art. 1 of the Bashford Dean Memorial Volume, and will indicate to me what articles they desire, I will forward these so far as they are available.

It may be some time before the actual sending out can be done, but I should like to have all requests in before the distribution is begun.

E. W. GUdGer.

Department of Ichthyology,

American Museum of Natural History,

77th Street and Central Park West, New York, N.Y. 